\title{
Teachers' Experiences on Instructional Design Based Professional Development: A Narrative Inquiry
}

\author{
Sertel Altun ${ }^{a}$, Defne Yabaşs,i, Hüma Bal-Nayman ${ }^{c}$
}

$\begin{array}{ll}\text { Received } & : \text { 22 March } 2021 \\ \text { Revised } & : \text { 15 August } 2021 \\ \text { Accepted } & : \text { 8 September } 2021 \\ \text { DOI } & : \text { 10.26822/iejee.2021.227 }\end{array}$

aSertel Altun, Faculty of Education, Yıldız Technical University, Istanbul, Turkey

E-mail: sertelaltun@gmail.com

ORCID: https://orcid.org/0000-00021951-5181

b; Corresponding Author: Defne Yabaş,

Faculty of Educational Sciences, Bahcesehir University, Istanbul, Turkey

E-mail: defneyabas@gmail.com

ORCID: https://orcid.org/0000-0001-5575-510X

'Hüma Bal-Nayman, English Language Prep School, Bahçesehir University, Istanbul, Turkey

E-mail: humabal1996@gmail.com

ORCID: https://orcid.org/0000-0001-5270-8965

\begin{abstract}
Empowering teachers as instructional designers strengthen the link between theory and good practice. The purpose of the research is to explore two teachers' experiences about a professional development (PD) program. The PD includes a one academic year program with the aim of developing teachers' instructional design knowledge and skills using Understanding by Design model as reference. Teachers' instructional designs improved in terms of UbD design principles, and they reported change in their attitudes and teaching practices after the fourth cycle. Continuous discipline-specific feedback and trust bond based on prolonged communication underlined as major elements of PD that facilitated teacher change.
\end{abstract}

\section{Keywords:}

Professional Development, Curriculum, Narrative Analysis

\section{Introduction}

onsidering the role of education in providing students with complex and high-level skills so that they can achieve self-realization and contribute to society, it is critical to use scientific knowledge for production, doing research by using gained information in their professional and daily life, problem solving and decision-making skills (Trilling \& Fadel, 2009). This brings the necessity of teachinglearning activities that are compatible with the current curriculum but can go beyond the attainments foreseen in the programs in terms of skills, reaching the student with authentic methods and putting student participation and performance to the forefront. Participation is especially important in terms of transformative competencies that empower students to shape the future (OECD, 2019). As $21^{\text {st }}$ skills became essential, more and more countries across the world give effort to adjust their educational systems to equip children and young people with the skills that go beyond 3Rs (Global Partnership for Education, 2020). School curricula were recommended to allow non-linear learning paths, be more flexible and relevant to unique characteristics and talents of students (OECD, 2019). Designing flexible learning environments that allow all students to experience $21^{\text {st }}$ century skills and fulfill their potentials, the participation 


\section{iejee}

of teachers in the instructional design process is very critical. The importance of teachers' involvement in the instructional design process along with their widely accepted implementations is also emphasized in literature (Kelly, 1999; Penuel \& Gallagher, 2009; Pinto, 2005). Similarly, in Turkish context more research studies have been carried out to empower teachers as designers (Hacıömeroğlu, 2018; Ozgen, 2019; Yurtseven \& Altun, 2019). The fact that teachers create their instructional design leads them to embrace this instructional design and to implement it more effectively (Ben-Chaim et al., 1994, Fullan \& Hargreaves, 1992, Voogt et al.,2016). Empowering teachers as instructional designers also strengthens the link between plan and implementation, thus ensuring that high-level skills are delivered to students efficiently.

\section{Teachers as Instructional Designers}

Although teachers' professional development (PD) as instructional designers are widely accepted in the relevant literature, how teachers will achieve this development still stands out as an open subject for research. At this point, directing teachers too little or too much during the design process can cause negativity during the design process (Pinto, 2005). Teachers were recommended to work with experts to adopt the aims and methods of instructional design and to be involved in an informed design process (Nieveen\&Van der Hoeven, 2011). Providing support by teacher educators in a PD activity is useful in terms of both the creation of the design and the learning processes of teachers (Clarke \& Hollingsworth, 2002; Garet et al., 2001; Putnam \& Borko, 2000). At this point, widely accepted effective practices about PD studies should also be considered. For example, DarlingHammond (2012) mentioned five important elements of effective PD as sustainable, content-based, embedded in professional learning communities, and original environments that include teaching, assessment, monitoring and reflection.

\section{Understanding by Design}

Along with the importance of empowering teachers as instructional designers in the context of professional development studies, the instructional design model to be used in these studies also become prominent. In this context, it becomes important to adopt an instructional design model that is compatible with the general objectives of education, which is holistic, includes all stages of the teaching-learning process and supports the teacher in terms of the activities to be carried out throughout the process.

Understanding by design (UbD) model, which emphasizes the designer role of the teacher among contemporary teaching design models and focuses on student learning, has been a model frequently preferred by teachers and school administrators. UbD is a design model that focuses on students' understanding and accepts learning as a process of discovery. In this process, while teachers act as mentors and facilitators, they create their designs with the philosophy of "backwards design", while students also try to achieve permanent understandings by exploring, questioning, and applying information to new areas (Yurtseven \& Altun, 2019). The most distinctive aspect of UbD is the backwards design approach. Backward design suggests firstly determining learning outcomes and assessment evidence, and then planning teaching-learning activities to gain these outcomes and evidence (Biggs \& Tang, 2011; \& Wiggins \& McTighe, 2005). Planning the learning process in line with the expected outcomes of students at the end of the process gives opportunity to focus on learning rather than teaching. In an instructional design that focuses on learning, content knowledge, teaching methods and materials used are in the second place in line with learning outcomes. In this way, UbD has three stages: (1) identifying desired results, (2) determining assessment evidence, and (3) planning learning experiences and instruction (Wiggins \& McTighe, 2005). The second distinctive aspect of $\mathrm{UbD}$ is that it focuses on student understanding. It suggests that understanding associates with making inferences and transferring the knowledge into new situations. It divides understanding into six facets as explanation, interpretation, application, perspective, empathy, and self-knowledge (McTighe \& Wiggins, 2012; Wiggins \& McTighe, 2005).

The reason why UbD is chosen for this study can be expressed with is teacher empowering aspect, focusing on student learning, and development of 21st century skills. From this point of view, the aim of the study is to examine teachers' UbD learning experiences within the PD program. We focused on the research question: What are the experiences of teachers throughout the PD program in terms of their improvement in instructional design knowledge and skills? To frame teachers' narratives, we had below sub-questions:

- How did the teachers' knowledge of UbD
design principles develop?

- How did the teachers' skills to prepare UbD plans develop?

- What are the experiences of the teachers about the class implementations of their instructional designs?

- How do teachers evaluate their changes in the PD process?

- Which goal do teachers set for themselves regarding their PD in the future? 


\section{Method}

We used the narrative study design, one of the qualitative research designs. Qualitative research includes studies aimed at understanding the experiences of individuals and determining what meanings individuals attribute to these experiences. In the narrative studies, the experiences of individuals related to their real-life situations are tried to be presented within the framework of their own stories. Individuals tell their experiences in a narrative way, with a beginning, middle, and end (Merriam \& Tisdell, 2016). Narrative studies aim to make inferences about how individuals understand situations, others and themselves (Polkinghorne, 2007). The difference of narrative studies from other qualitative research designs is that it helps others or individuals to organize their own actions, experiences and events in a meaningful way and relates the consequences of actions and events over time. Within the scope of narrative studies, some or all of the lives of individuals can be included, as well as shorter and focused studies (Chase, 2011).

Narrative studies should have dimensions of situation, continuity, and interaction. Accordingly, narrative studies are individual interactions that take place depending on a situation, focusing on the past, present, and future (continuity) (Connelly \& Clandinin, 1990). From this point of view, the study focused on the changes in knowledge, skills, and attitudes of the two teachers about the UbD process, their past and current PD participation; and their expectations for the future were identified. Similarly, the researchers made suggestions for the PD process based on the past and present experiences of the participants. Detailed information about the participants and the PD process was included to form the context of the teacher's narratives. The interaction with the participant teachers continued at all stages of the PD process and during the interviews.

To describe the narratives of the teachers' experiences these steps are followed:

- Before the PD process, teachers were interviewed. Their expectations from the process were asked,

- PD trainings were provided to teachers based on the UbD model for developing instructional design,

- Teachers prepared their first UbD designs,

- Teachers were given feedback about their designs in the interim meetings, and finalized the design by making the necessary revisions,

- Teachers prepared their second, third and fourth instructional designs respectively,

- Teachers implemented the instructional designs in the classroom,
- Interim meetings were held with teachers to hear their opinions about the process.

\section{Participants}

The participant teachers are one Turkish Language and one Science teacher working in a private school in Istanbul at the secondary school level. To present the narratives of teachers' learning experience we selected two teachers from two different disciplines and are willing to explain their learning process in more detail. The participant teachers were both task oriented, they were motivated to pursue the professional development program. Turkish language teacher had intrinsic motivation to learn instructional design, however, the science teacher is more extrinsically motivated to complete the tasks within the professional development program. They were both in management positions for their departments. In this sense, their thoughts about the professional development program could reflect the overall views of the other teachers in their departments. This selection of participants allowed us to compare two different stories of teachers.

Turkish Language Teacher: She graduated from Turkish Language Teaching Undergraduate Program. After graduation, she worked as a Turkish Language teacher for four years at a public school, and later as a Turkish Language teacher at private schools. She has been working at her current school for ten years. For the last three years, she has been working as the secondary school vice principal as well as head of the Turkish Language department. She completed her 24th year in the profession. She adopts student-centered teaching as a learning approach. She is a teacher open to innovations but accepts such innovations if the innovations will make a difference in the teaching environment. She prefers to work in cooperation with her colleagues as a professional principle.

Science Teacher: She graduated from Science Teaching Undergraduate Program. After graduation, she worked as a science teacher in a public school for twenty years, and after retiring from there, she worked as a science teacher in private schools. She has been working for eight years at his current school. For the last two years, she has been the head of the science department. She completed her 30th year in the profession. She adopts child-centered teaching as her learning approach. She contributes to the innovations suggested by the school. She believes that she will be successful in PD training if she is given the right consultancy.

\section{Professional Development Process}

This study was carried out throughout 2018-2019 academic year. The content and process of PD 


\section{iejee}

experience is arranged around two major domains: Initial UbD Training and UbD teaching practices. Initial UbD training included a three-day seminar and workshop series with the aim of increasing teachers' knowledge about UbD. UbD teaching practices domain covered teachers' activities and researchers' feedback and observations. There were four mechanisms to support UbD teaching practices: (1) Creating instructional designs, (2) researchers' feedback, (3) class implementations and observations, (4) interactive meetings. Four cycles of teaching practices took place throughout the PD process.

Before starting the PD, a meeting was held with the school principal and two participant teachers as the heads of science and Turkish language department. In this meeting, researchers and teachers discussed about professional experiences of the teachers, their previous UbD PD experiences, and their expectations from the new UbD PD. In the new PD process, the teachers specifically underlined that practicality, teamwork, guidance, supervision, and feedback elements should be incorporated in the PD process. The school management and the teachers also suggested to include weekly interactive meetings to receive specific feedback and guidance.

First Cycle: Initial UbD Training took place within the summer seminar program of the teachers. Besides seminars and workshops, teachers developed their first UbD instructional design. Researchers gave feedback and teachers revised their designs. Teachers mostly encountered difficulties about specifying the big idea, formulating understanding expressions, asking essential questions, planning student-centered implementations, supporting individual differences, and organizing process-oriented assessment tools. Researchers gave their feedback specific to those issues. After the revisions, teachers implemented their first instructional design in their classes.

After the class implementations, first interactive meeting took place. Teachers raised time management, classroom management, student motivation and permanent learning issues about their class implementations. For the initial classroom implementations, teachers reported not being comfortable in the classroom as they used to be. In this interactive meeting, additionally, researchers provided activity samples about participatory learning methods to be included in UbD designs Also, reading materials about formative assessment tools were assigned.

Second Cycle: Teachers developed their second instructional design. Researchers observed a positive development especially in the use of UbD components in the designs. Teachers used the participatory methods in their designs, but they were weak in creating differentiated learning activities. Teachers revised their second designs in line with the researchers' feedback and implemented them in their classes. In the second interactive meeting, teachers discussed about their class implementations. Teachers presented student products, photos, and videos from the implementations. Particularly, students' interest and motivation encouraged teachers more. Teachers reported being more comfortable and flexible than the first class implementation. Researchers, additionally, showed examples of differentiated learning activities. Teachers ask their questions and were assigned with further reading materials.

Third Cycle: Teachers developed their third instructional design. In the third design, it was observed that the teachers became more competent in creating UbD designs. Researchers' feedback in this process consisted of integrating formative assessment tools and technology in their designs. Teachers revised their third designs in line with the researchers' feedback and implemented them in their classes. In the third interactive meeting, teachers discussed their class implementations. They showed the student products, photos, and videos. In this process, teachers mostly started a self-evaluation process. It has been observed that they are willing to express their own development, strengths, and weaknesses.

Fourth Cycle: Teachers individually developed their fourth designs. The researchers reviewed the designs and provided feedback. The designs of teachers were very competent in terms of UbD components. The fourth designs were implemented in the lessons and this time the researchers observed class implementations. Researchers shared their notes from the observations with the teachers.

At the end of the fourth cycle, individual interviews were conducted with the teachers regarding the whole PD process.

\section{Data Collection}

The main data source of narrative study is the texts consisted of the stories of the participants (Merriam \& Tisdell, 2016). Hence, the texts related to interviews in which the participants describe their experiences of instructional design from the beginning to the end of the process constitute the primary data source of the study. Data collected through the interviews were supported by classroom observations and document review techniques.

\section{Interview}

Semi-structured, face-to-face interviews were held with the teachers to encourage them reflect about the professional learning process from the beginning 
until the end. Two researchers conducted the interview together. The interview protocol included the following questions:

- How would you describe the instructional design learning and development process you have experienced since the beginning of the school year?

- What were your views and experiences about UbD instructional design before starting the education process?

- How would you evaluate the UbD instructional design training held within the scope of PD? What do you think of its effectiveness?

- How would you describe your experience when you implemented your instructional designs in the classroom? What did you feel, what were your students' reactions?

- What would you suggest to teachers who will be trained about instructional design?

The interviews lasted 60 minutes with the Turkish Language teacher and 45 minutes with the science teacher. The interviews were audio-recorded, and field notes were taken by one of researchers.

\section{Classroom Observations}

Researchers observed the class implementation of the final (fourth) designs developed by each teacher. During the observations, the main issues were on to what extent teachers were able to implement the activities in their designs, how they included UbD principles, the communication atmosphere they created in the classroom, time, and classroom management, and to what extent they motivated students to understand. The researchers acted as nonparticipant observers in the classroom and took notes regarding their observations.

\section{Document Review}

Researchers examined four UbD designs developed by each teacher. The designs were scored according to the UbD elements: identifying expected outcomes, the appropriateness of the big idea, essential questions, knowledge, skill, understanding and transfer expressions and the consistency between these elements. To examine assessment evidence, the emphasis was on the relationship between summative and formative assessment tools with expected outcomes and learning activities. In planning learning activities, WHERETO principles were examined.

\section{Data Analysis}

To analyze data from interviews content analysis was used. The audio recordings were converted to text, meaningful units that would be the basis for coding in the text were determined and coded. Both researchers read the text many times and reviewed their coding. The researchers once went through the codes together, the agreed codes were accepted directly, and the incompatible codes were discussed and agreed. In the next step, the related codes were brought together, and the themes were determined. Codes and themes were presented in before and after professional development process so that they complement overall narrative of the teachers.

The designs developed by the teachers were put to document analysis. The rubric related to the UbD design principles was used for document review.

The data obtained from the notes taken during the classroom observations were analyzed with the descriptive analysis method.

\section{Validity and Reliability}

In qualitative approaches, credibility and consistency for internal validity, transferability and confirmability for external validity should be met (Lincoln \& Guba, 1985). Firstly, a prolonged interaction with the participants was provided in the context of PD that continues throughout one academic year. Data obtained through different tools were subjected to prolonged analyzes repeatedly. Researchers had the opportunity to compare, review and confirm the data they obtained from different tools through multiple data collection methods, including interviews, classroom observations, document reviews, and observation notes. All data obtained from the study were analyzed separately by two researchers. Shared forms of which consistency was tested, were sent to two methodologists for expert opinion. The data obtained from the research were explained by giving direct quotations. In addition, the context and process of the research were shared in detail. To ensure the consistency of the research, the whole process, the methods used, and the decisions taken were recorded. In line with the research questions, data collection tools were prepared and reported by considering the UbD instructional design. Each step of the research was carried out by seeing the big picture from beginning to end. Findings were compared with original data. The codes and themes obtained from the data analysis and detailed findings were shared with the participants for member checking procedures. Participants confirmed the results found by the researchers within the scope of data analysis and findings.

In qualitative research, researchers are also expected to express their view of the subject and what they expect from the research. The study was conducted by three researchers. The first researcher has been working as a lecturer in the education faculty of a state university and received a PhD degree in Curriculum and Instruction. The second researcher took part in the study received a PhD degree in Curriculum 


\section{iejee}

and Instruction and has been working as a lecturer at a research center of a private university. The third researcher is a associate professor in a private university who is also a PhD student in Curriculum and Instruction. All three researchers have taken part in many national and international projects and studies as experts in teacher education, educational programs, and instructional design. First researcher is editor of three books, and second researcher contributed to wo books on UbD. Within the scope of the current research, the first two researchers took the role of planning, implementation, observation, development, and feedback of PD. Three researchers took equal part in the reporting of the research.

\section{Results}

The results of the study were presented chronologically as before, during and after the PD process in accordance with the nature of narrative research. The answers to the research questions were discussed under these three headings.

\section{Before Professional Development Process}

In interviews, teachers were asked to express their UbD knowledge and previous learning experiences before the PD process. Participating teachers attended a PD for UbD-based instructional design one year ago in the same school, but they stated that the training was not generally efficient for them and created a negative attitude at some points. With this previous training, teachers acknowledged the concept of UbD in instructional design. While the Turkish Language teacher associated the UbD design process with previous knowledge in the form of designing the lessons in the introduction, development, and conclusion stages at this point, the science teacher did not associate the UbD design process with any of the processes she previously knew.

When the teachers were asked about this previous learning experience, it was understood from their expressions that they had a strong negative attitude, such as, "It was horrible", "I hated it". Teachers who define their pre-learning experiences with these expressions mostly attributed their negative attitudes to the roles of instructor-teacher and the lack of communication with the instructor: "First, we were passive listeners. We were in a passive position, not in an active position." and "there was no sincerity, we had trouble getting feedback".

In short, teachers' expressions about their preeducational experiences indicated that they started PD process with a strong negative attitude and limited UbD knowledge.

\section{Professional Development Process}

Teachers talked about the initial UbD training through a more positive perspective, despite the negative thoughts they brought to the educational environment. They associated these positive perspectives with the trainer characteristics and the training processes handled. By the words, "You were very sincere, we were 4-5 groups in the activity, you saw everyone in the group-play, I was amazed how it happened. Now we see it too." and "the competence of the incoming instructors is important to our attitude" they defined instructors' characteristics as sincere and competent. The topics they highlighted the most in the training processes were active participation and feedback regarding the process. The Turkish Language teacher gave an example by this expression; "We were very active in the education process, we constantly produced something, we received very effective feedback, it was very good that we were guided to do it (the plans) in a correct way."

Instructional design development, weekly interactive meetings and observation of classroom implementations took place at the second stage of the PD process. For this stage, the teachers again emphasized the importance of feedback. The teachers gave detailed views on feedback and drew attention to the constructiveness of the process and its being related to the teacher's field: "Your criticisms are constructive with proper language. Therefore, I read it again and evaluated it. This is how we can get criticism better. Trust is won this way." and "seeing examples, good and bad, is an opportunity for improvement. It was good to get feedback on our field. It doesn't feel good when I don't see depth in my field.". The teachers stated that they started to notice the lack of knowledge in the previous training during the interactive meetings. During the class implementation, they spent effort, although they had difficulty at the beginning.

For the research question "How do the teachers' skills to prepare instructional design based on UbD develop?", four instructional designs developed by each teacher were examined with the rubric including design standards, and the total scores were obtained by scoring over 3 for each criterion.

Results related to the evaluation are shown in Table 1.

Table 1 shows each teacher made a noticeable improvement in designing unit plans in accordance with design standards. The design skill of each teacher showed a certain improvement. The improvements were reflected in the total score and grand total scores of the teachers in each design. However, it was seen that the increase in the design scores of the Turkish teacher was higher than the design skill of the science teacher. 
Table 1.

Evaluation Results of the UbD Instructional Design

\begin{tabular}{|c|c|c|c|c|c|c|c|c|}
\hline \multirow[b]{2}{*}{ Unit plan; } & \multicolumn{4}{|c|}{ Science } & \multicolumn{4}{|c|}{ Turkish Language } \\
\hline & I. & II. & III. & IV. & I. & II. & III. & IV. \\
\hline \multicolumn{9}{|l|}{ Stage 1: Expected Outcomes } \\
\hline $\begin{array}{l}\text { 1.Describes ideas that are worth understanding/researching, transferable } \\
\text { and essential. }\end{array}$ & 1 & 1 & 2 & 2 & 1 & 2 & 2 & 3 \\
\hline $\begin{array}{l}\text { 2. Defines understanding objectives as generalizations in full sentences: } \\
\text { Students will understand..... }\end{array}$ & 1 & 1 & 2 & 2 & 1 & 2 & 3 & 3 \\
\hline $\begin{array}{l}\text { 3. Indicates long-term transfer objectives that are desired and require real } \\
\text { success. }\end{array}$ & 1 & 2 & 2 & 3 & 1 & 2 & 3 & 3 \\
\hline $\begin{array}{l}\text { 4.It includes several essential questions that are open-ended, stimulating } \\
\text { and focusing on thinking. }\end{array}$ & 1 & 2 & 3 & 3 & 2 & 2 & 3 & 3 \\
\hline 5. Define the standards, tasks and program objectives required for all stages. & 1 & 2 & 2 & 3 & 1 & 2 & 3 & 3 \\
\hline $\begin{array}{l}\text { 6. Define the necessary knowledge and skills to reach understanding and } \\
\text { fulfill the general objectives. }\end{array}$ & 1 & 2 & 2 & 2 & 2 & 2 & 3 & 3 \\
\hline 7. All the elements listed above are in harmony with each other. & 1 & 1 & 2 & 2 & 2 & 2 & 3 & 3 \\
\hline Stage 1 Total Points & 7 & 11 & 15 & 17 & 10 & 14 & 20 & 21 \\
\hline \multicolumn{9}{|l|}{ Stage 2: Assessment Evidence } \\
\hline $\begin{array}{l}\text { 8. Defines valid assessment evidence that will lead to all the expected out- } \\
\text { comes. }\end{array}$ & 1 & 1 & 2 & 2 & 1 & 2 & 2 & 3 \\
\hline $\begin{array}{l}\text { 9. Includes authentic performance tasks based on one or more indicators of } \\
\text { understanding. }\end{array}$ & - & 1 & 2 & 3 & 2 & 2 & 3 & 3 \\
\hline 10. It provides enough opportunities for students to succeed. & 1 & 1 & 2 & 2 & 1 & 1 & 2 & 2 \\
\hline $\begin{array}{l}\text { 11. It includes assessment criteria to ensure that each task is compatible with } \\
\text { the desired results and provides appropriate feedback on performances. }\end{array}$ & 1 & 2 & 2 & 2 & 1 & 2 & 2 & 2 \\
\hline Stage 2 Total Points & 3 & 5 & 8 & 9 & 5 & 7 & 9 & 10 \\
\hline \multicolumn{9}{|c|}{ Stage 3: Planning learning experiences } \\
\hline 12. It includes learning activities and instruction to help learners to: & & & & & & & & \\
\hline a. Obtain targeted knowledge and skills, & 1 & 1 & 2 & 2 & 1 & 1 & 2 & 3 \\
\hline b. Make sense of big ideas, & 1 & 1 & 2 & 3 & 1 & 2 & 2 & 3 \\
\hline c. Transfer what they have learned to new learning environments. & 1 & 2 & 2 & 3 & 1 & 2 & 3 & 3 \\
\hline $\begin{array}{l}\text { 13. Uses WHERETO principles effectively to make the unit attractive to all stu- } \\
\text { dents. }\end{array}$ & 1 & 1 & 2 & 2 & 1 & 2 & 3 & 3 \\
\hline 14. All stages of the design are in harmony with each other. & 1 & 1 & 2 & 2 & 1 & 2 & 2 & 3 \\
\hline Stage 3 Total Points & 5 & 6 & 10 & 12 & 5 & 9 & 12 & 15 \\
\hline
\end{tabular}

*1: low, 2: medium, 3: high

When the science teacher's UbD designs were examined, it was found that there was a significant improvement especially in the big idea, essential question, meaning and transfer expressions. In the first design, superficial expressions were preferred at the level of knowledge, but in the final design, the transfer between deep knowledge and real life was expressed more clearly. However, it was seen that the desired level was still not accomplished in the comprehension statements. In Table 2, this development was shown with first and fourth design examples.

Another striking issue in the initial design, science teacher did not include the performance task supporting the summative assessment, she only used the tools to test students' knowledge. On the other hand, in the fourth design, the performance task was clearly expressed, and in the formative assessment, teacher included tools for the evaluation of the learning process as well as the assessment of the knowledge attainments. Table 3 shows the improvement on first and fourth designs in terms of UbD's assessment and evaluation component.

The most significant improvement in designs was seen in the preference of methods that can hook the learners in the process. Although, the teacher did not include the activities that support individual differences in the first design, it was included in the 
Table 2.

Improvement on Expected Outcomes

\begin{tabular}{|c|c|c|}
\hline \multirow[t]{2}{*}{ Big Idea } & First design & It is emphasized that weight is a force. \\
\hline & Fourth design & Electrical energy turns into light, heat and motion energy. \\
\hline \multirow[t]{2}{*}{ Essential question } & First design & $\begin{array}{l}\text { Under what force does an apple standing on a tree fall down from } \\
\text { the tree? }\end{array}$ \\
\hline & Fourth design & How is electrical energy transformed into other types of energy? \\
\hline \multirow[t]{2}{*}{ Understanding } & First design & Student learns to use dynamometer. \\
\hline & Fourth design & Student understands that there are electric charges. \\
\hline \multirow[t]{2}{*}{ Transfer } & First design & $\begin{array}{l}\text { Student understands that the force of gravity affecting the mass } \\
\text { is weight. }\end{array}$ \\
\hline & Fourth design & $\begin{array}{l}\text { Student takes the necessary precautions for the safety of life and } \\
\text { property by considering the implementations of grounding in daily } \\
\text { life and technology and emphasizes its importance when neces- } \\
\text { sary. }\end{array}$ \\
\hline
\end{tabular}

Table 3.

Improvement on Assessment and Evaluation

\begin{tabular}{|c|c|c|}
\hline \multirow{3}{*}{$\begin{array}{l}\text { Summative Assessment } \\
\text { Performance Task }\end{array}$} & First design & - \\
\hline & Fourth design & Open ended exam \\
\hline & & Performance task \\
\hline \multirow[t]{5}{*}{ Formative Assessment } & First design & Graphic drawing \\
\hline & & Diagnostic branching tree \\
\hline & Fourth design & Question answer \\
\hline & & Self-assessment \\
\hline & & Experiment sheets \\
\hline
\end{tabular}

Table 4.

Improvement on Learning Experiences

\begin{tabular}{lll}
\hline Hooking students & First design & Experiment \\
\cline { 2 - 3 } & Fourth design & $\begin{array}{l}\text { Group work } \\
\text { Experiment } \\
\text { Discussion }\end{array}$ \\
\hline \multirow{2}{*}{$\begin{array}{l}\text { Tailoring learning by different } \\
\text { needs }\end{array}$} & - \\
\cline { 2 - 3 } & First design & $\begin{array}{l}\text { In the performance task, students will be able to differentiate their } \\
\text { products according to their interests and learning styles. }\end{array}$ \\
\hline
\end{tabular}

\section{Table 5.}

Improvement on Desired Results

\begin{tabular}{|c|c|c|}
\hline \multirow[t]{2}{*}{ Big Idea } & First design & $\begin{array}{l}\text { The story, which is a literary genre, is divided into genres according } \\
\text { to the author's approach and point of view; a story can be } \\
\text { reproduced according to the author's different points of view. }\end{array}$ \\
\hline & Fourth design & $\begin{array}{l}\text { Poetry allows us to express our feelings and thoughts using few } \\
\text { words. }\end{array}$ \\
\hline \multirow[t]{2}{*}{ Essential question } & First design & $\begin{array}{l}\text { What are the characteristics that allow us to classify stories as } \\
\text { event stories or situation stories? }\end{array}$ \\
\hline & Fourth design & $\begin{array}{l}\text { What causes us to like some poems more and be influenced more } \\
\text { by these poems? }\end{array}$ \\
\hline \multirow[t]{2}{*}{ Understanding } & First design & $\begin{array}{l}\text { Student understands the characteristics that distinguish between } \\
\text { situation and event stories. }\end{array}$ \\
\hline & Fourth design & $\begin{array}{l}\text { Student understands that the subject and main emotion of the } \\
\text { poem are effective in determining the genre of the poem. }\end{array}$ \\
\hline \multirow[t]{2}{*}{ Transfer } & First design & Student gains reading pleasure and habit. \\
\hline & Fourth design & $\begin{array}{l}\text { Student realizes that the emotion that dominates the poem } \\
\text { determines the genre. }\end{array}$ \\
\hline
\end{tabular}


performance task of the fourth design. Table 4 shows the improvement on first and fourth designs.

When the Turkish Language teacher's UbD designs were examined, significant improvement was observed, especially in the big idea, essential questions, understanding and transfer expressions. In the final design, it was observed that the expressions of big ideas, essential questions, understanding, and transfer were clearer and encourage higher-level thinking. UbD components were also in harmony with each other. The first and fourth design examples of this development were shown in Table 5.

Another noteworthy element in designs was that evaluation tools developed in favor of the fourth design in both quantitative and qualitative terms. The Turkish Language teacher included a result-oriented performance task in the initial design and final design. However, whereas tools examining students' knowledge attainment were preferred in the first design, in the latest design, tools evaluating learning processes were included in addition to knowledge acquisitions. It was seen that formative assessment also included self-assessment tools. The first and fourth design examples of this development were shown in Table 6.

The most distinctive development in designs was that the methods that can hook the learners in the process were included more in the latest design. At the same time, implementations that allow individual differences were used more in many stages of the design. In the first design, the teacher included only the reading circle activity as a participatory method, whereas in the final design, discussion, group work and cooperative learning methods were used to support various skills of students. While the only activity that took individual differences of the students into consideration was the reading circle in the first design, activities addressing individual differences were incorporated both int the learning process and in the performance task. The first and fourth design examples of this development were shown in Table 7.

Researchers observed the class implementation of both teachers' final designs. Teachers used the following expressions regarding classroom observations while implementing a part of their lesson designs:

\section{Table 6.}

Improvement on Assessment and Evaluation

\begin{tabular}{|c|c|c|}
\hline Summative Assessment & First design & Exit cards \\
\hline \multirow[t]{7}{*}{ Performance Task } & & Performance task \\
\hline & Fourth design & Structured grid \\
\hline & & Attainment test \\
\hline & & Cooperative learning worksheet \\
\hline & & Google form \\
\hline & & Performance task \\
\hline & First design & Open ended questions \\
\hline \multirow[t]{5}{*}{ Formative Assessment } & & Teacher observation \\
\hline & Fourth design & Open ended questions \\
\hline & & Peer-assessment \\
\hline & & Teacher observation \\
\hline & & Self-assessment \\
\hline
\end{tabular}

Table 7.

Improvement on Learning Experiences

\begin{tabular}{lll}
\hline Hooking students & First design & Reading circle \\
\cline { 2 - 3 } & Fourth design & $\begin{array}{l}\text { Discussion } \\
\text { Group work } \\
\text { Cooperative learning }\end{array}$ \\
\hline Tailoring learning by different & First design & $\begin{array}{l}\text { Students will be supported by taking different roles in the reading } \\
\text { circle. }\end{array}$ \\
\cline { 2 - 4 } & Fourth design & $\begin{array}{l}\text { Students will take roles according to their individual differences in } \\
\text { the cooperative learning process. } \\
\text { Those who choose to speak at the discussion event will be given } \\
\text { the opportunity. } \\
\text { In the performance task, students will determine the poet and } \\
\text { poetry according to their interests, and they will both tell the poet } \\
\text { and show poetry performance according to their abilities. }\end{array}$
\end{tabular}


"I was excited. Nobody has been in my class for a long time. I was excited but I said stop to myself because everything was already planned. The plan reduced my excitement. When I did what I had to do, everything went well. "- Turkish Language Teacher

"If we hadn't received feedback, we wouldn't have done the lesson observation process so comfortably." - Science Teacher

The teachers drew attention to the fact that they planned their UbD designs in detail and this helped them with the implementation. They also appreciated the feedback and guidance they received.

Researcher's observation notes, focused on student learning, the effectiveness of the use of participatory methods and the appropriate use of essential questions in both teachers' lessons. At this point, the researcher's observation notes and the document review results on teachers' instructional designs are compatible with each other.

\section{After Professional Development Process}

When teachers evaluated their knowledge and attitudes as a result of the PD process, they described one of the basic points they learned during the experience of instructional design process based on UbD as effective planning knowledge:

"It makes the teacher's job easier. The preparation process is difficult, but it gets easier afterwards, your job is easier, you are comfortable. The units I process with UbD became more permanent. I did not believe this in the past, now I do."

They stated that they can evaluate the unit holistically regarding this planning competence, they are more effective in classroom and time management, and they can ensure permanent learning by activating students. When the teachers said that they focused on student participation, they expressed their opinion by; "The children are bored with everything we do which do not make children active. It offers the teacher an opportunity to keep the student active in the classroom. More permanent than our lecturing" and "It makes me plan individualized plans. I could do it with one activity for the whole class, but I couldn't reach all of them. It is perfect for the new generation. We have to change because they have changed.". Teachers' views on classroom and time management are as, "Planning is very important and it provides classroom control when you have your way planned." and "I thought units would take longer time before, it takes even shorter now. It is time saving which is a huge advantage".
It is noteworthy that the teacher's designing their lessons effectively is described as a facilitating and relaxing process. The Turkish Language teacher expressed this situation by, "It is something that relieves the teacher conscientiously. It also relaxes me when I look at it as a manager. Management systems also relax."

When teachers were asked what new goals they have for their PD after the process, they stated that they wanted to improve themselves in increasing student motivation in the first place. "More learning techniques to increase motivation in the classroom. This group of students is everywhere, and the most important thing is to provide motivation for them", "To increase the motivation to learn. It proceeds very well after the students have studied and produced by themselves. We were wondering if they were learning in chaos. They learn from each other. " and "When I'm in class, the classroom should be well behaved, I was a little strict, it is the only way that they can pay attention. If they deal with something else, they can't listen to me. But now it's different. A year and a half ago, speaking was a chaos for me. If we change, they will change." statements show that teachers focus on classroom dynamics and the student's desire to learn.

The teachers also stated that they want to focus on differentiation to make UbD plans more effective.

\section{Discussion}

In this study, the PD process of one Turkish language and one science teacher were examined. Teachers worked on the UbD instructional design in the PD process. Teachers' experiences throughout the learning cycles of the PD were reported in terms of before, during, and after PD phases.

Both teachers stated that they had no knowledge of UbD when they first received UbD training and that UbD has very different elements compared to previous designs. Teachers had little prior experience in terms of lesson planning. Throughout their prior UbD training experience, the main difficulty was the general attitude of the instructor. The instructor behaved very cold towards them, was closed to communication, presented the subject by simply explaining it straight away, and teachers were passive. For this reason, the teachers emphasized that they did not enjoy the first UbD training process at all, were not willing to understand, and had a negative attitude towards the subject. Later in the process, especially the Turkish Language teacher was not involved in this design process, and only the science teacher developed the lesson design. However, because the instructor's feedback was limited to good, medium, and wrong expressions for the whole design, the science teacher 
stated that she did not have any information about where she did it wrong or right. She expressed that her motivation for making the next design was low and she was confused about what to do. The Science teacher stated that she developed three designs because the school administration asked her to do, but she did not have enough knowledge and skills to create UbD designs. The negative attitude towards PD experiences can be attributed to the attitude differences between those who decide to change (management) and practitioners (teachers) in the literature (Maskit, 2011) and the management's view about teachers (Desforges, 1995; Fullan, 2007). Also, components of the given training can also be examined in relation to the design (Garet et al., 2001; Newmann et al., 2000) and the instructor's approach (Harris et al., 2014). Studies related to the effect of the instructor's approach on PD have shown that the role adopted by the instructor and the support systems impact has an impact on the effectiveness of PD (Blank \& de las Alas, 2009; Cavanaugh, 2013; Guskey \& Yoon, 2009; Zaslow et al., 2010).

In the context of this study, when the school administration informed the teachers that they would receive training for the second time from another instructor on UbD, the teachers requested a meeting from the instructors who would provide UbD training. Also, they stated that they would express their requests from the instructors about this process in order to prevent the negativity in the previous UbD training experience. A meeting was held where teachers, school administrator and instructors came together. In this process, the teachers stated that they wanted a sincere educational environment because they felt more comfortable in a friendly environment and could easily ask the questions they had in their minds. Many studies have discussed the effects of teachers' emotions on PD (Avalos, 2011; Golombek \& Doran, 2014). Studies have shown that the interaction between emotions and cognitive processes plays a role in the teachers' professional identity formation (Bullough, 2009; Dang, 2013; Starkey et.al., 2009). In addition, they wanted workshops besides the seminars, which allow them to develop UbD designs. In addition, the teachers insisted on receiving feedback about their work with detailed explanations, and suggestions should be given for the proper stages of the design, the stages they did wrong and the corrections of their mistakes. In addition to the requests, teachers also negotiated about holding weekly interactive meetings to discuss about the designs and class implementations. Researchers organized the PD process considering the requests of the teachers and the school management. After the initial UbD training, teachers revealed that they enjoyed the process and felt safe. The instructors' being friendly, sincere towards them and being competent in the activities they told and practiced has a great effect on the formation of the learning atmosphere. Teachers were encouraged to participate and to ask questions. In this way, they developed their UbD knowledge more accurately. The effects of mutual interaction on learning because of the creation of a positive learning environment in the PD process have been discussed in the context of socio-cultural learning theory (Mahn \& John-Steiner, 2002; Vygotsky, 1994). Socio-cultural theory draws attention to the need for teachers' cognition, emotion, and action domains to be handled together in the professional learning process (Golombek \& Doran, 2014). In particular, a new action plan for the needs of teachers was determined and implemented at each interactive meeting.

Both the science teacher and the Turkish Language teacher pointed out that they found a similarity between the UbD design process with learning a new language and that it was a difficult process as well. UbD has many different elements compared to other design models. Teachers' previous design experiences include a planning process of at most two hours, while the UbD design process includes $12-20$ class hours. Due to this unfamiliarity, teachers associated UbD learning with a foreign language learning. In particular, the teachers stated that they had difficulties in formulating big ideas, determining performance tasks, and planning the process according to students' differences. Those processes do not mostly take place in traditional planning. Therefore, it is a natural result that teachers have difficulties because they do not have experiences. Teachers were content about detailed and constructive feedback about their designs, sample designs and activities relevant to their field, and therefore, they made rapid progress in their knowledge and skills in the design process. These views of teachers are consistent with studies that focus on shaping PD according to the needs of teachers and establishing a solid support system and continuous feedback (Aelterman et al., 2013; DarlingHammond et al., 2017). According to teachers, the trust bond formed over time between the instructors and themselves had a very important place for the development of teachers' UbD designing skills. Teachers appreciated that instructors continuous support, and their competence in design and their guidance on the subject without offending the teachers may have caused them to establish trust. These components are thought to cause teachers to develop a positive attitude towards PD and are also related to the effectiveness of PD (Torff \& Sessions, 2008)

Both teachers stated that they were in a hurry to complete the design at first class implementations, therefore they did not focus much on the effect it creates on the students. However, later, they realized that they developed their knowledge and skills in the design process; they learned from the experiences 


\section{iejee $\approx$}

of each other at the interactive meetings; and that they showed positive change and development in the classroom implementations with the suggestions of the instructors. Teachers stated that as the process moved on, the focus in the classroom was the students' learning. Even they changed the activities that students did not enjoy, they kept getting feedback from students, and they encouraged students to work on more original and creative tasks, both in the learning process and performance tasks. Since teachers felt incompetent about $\mathrm{UbD}$ in the first designs, they were weak in reaching the students in the classroom environment or in motivating the students. However, over time, as they became competent in the design process and understanding the basics of UbD, namely the importance of understanding by the student, may have led to the development of communication and interaction with students in the classroom. The teachers stated that the positive development they observed in their students created a motivating force for them to do the next design better. As teachers saw the positive effect of using different materials in the classroom environment, using methods that make the student active, receiving feedback from them, giving opportunities to develop products; they gave more space to that type of activities and games, and supported students' individual differences. This was the most important breaking point of teachers in the UbD design process. The positive reflection of the training they received in the classroom environment by the students created an important source of motivation for teachers to give importance to the PD and to learn more about UbD designs. In the relevant studies, the positive reflection of the subjects and methods addressed in the PD process on the classroom environment has been considered as one of the most important factors in teachers' change (Armor \& Yelling, 2007; Garet et al., 2001; Guskey, 2002, Wayne et al., 2008).

Researchers observed improvement in the final designs compared to the initial UbD designs of both teachers, with the guidance and feedback they received. Particularly, teachers were eager to develop designs in the desired quality as they saw the suggestions that they received from the instructors had impact on students' learning in the classroom, motivation, and products. When the designs of science and Turkish Language teachers were examined separately, it was observed that the designs of the Turkish Language teacher showed more improvement than science teacher's design. The Turkish Language teacher has a personality supporting her to ask detailed questions. In the interactive meetings, she asked more questions to the instructors to understand the subject. In addition, when she thought that the designs were not of the desired quality, she requested additional time to complete the design. In addition, Turkish teacher had more private school experience and spent more time in various PD activities. All these reasons may have enabled the Turkish Language teacher to create UbD designs providing reach learning opportunities for students.

Teachers' opinions about the PD after the process revealed remarkable findings. Both teachers stated at the beginning of the UbD training, they believed UbD designs would cause difficulties in organizing the curriculum, but the UbD designs saved time. The teachers emphasized that determining the big idea while planning the UbD design process provides an important concept in determining the outline of the subject, a main framework in teaching principles, and enables to eliminate unnecessary details in the unit. At this point, it is thought that the structure of the UbD focused on essential questions designed around big ideas helps teachers. In this way, students can reach more meaningful meta learning outcomes (Tomlinson \& McTighe, 2006; Wiggins \& McTighe, 1998). Big ideas and essential questions force teachers to prioritize the gains that students want to see in their lessons (Erickson, 1998).

As another finding, the teachers stated that the UbD design process requires effort and embracing a holistic approach by designing was not easy. Teachers pointed out that many factors affecting teaching were handled separately in the previous design process, so while having an analytical thinking structure before, it is very important to have a holistic thinking process when creating UbD designs. They also expressed that it was not easy to get used to this way of thinking and it was necessary to have time. A planning process based on UbD encourages teachers to think more holistically by focusing on basic concepts and to build relationship between outcomes through big ideas (Wiggins \& McTighe, 2011; Seeger et al., 2018; Virgin, 2014). Teachers emphasized that planning was very important in the teaching process, a good planning facilitated the class implementation process, increases interaction, and contributes to meaningful learning. In many studies, it was concluded that a good lesson plan is effective in asking quality questions, increasing classroom interaction and realization of conceptual learning (Ding \& Carlson, 2013; Drost \& Levine, 2015; Li et al., 2009).

The plans for their future PD activities were centered around students' needs and motivation. Teachers still felt incompetent in differentiating activities according to students' needs. They wanted to participate at PD on differentiated instruction methods, techniques, and assessment. In addition, teachers stated that the factor that determines the desired quality of activity in classroom practices was student motivation. They emphasized that the different interests and needs of the students also differentiated the factors that motivate them; so that they should refresh their 
knowledge about providing student motivation. In this process, it emerges as a very important finding in that the needs of students are the main determinant in planning the PD of teachers (Aelterman et al., 2013; Avalos, 2011; Desimone, 2009; Garet et.al, 2001; Guskey, 2002).

\section{Conclusions}

Based on the narratives of the teachers, we can conclude the major effective elements of future PD as following:

Before starting the PD process, it is necessary to have interviews with teachers about their expectations in terms of content and methodology. In this meeting, all the stakeholders, i.e., instructors, school administrators, head of the departments and teachers, should be present. The questions such as "what are the teachers' PD needs?" "How the training will be held?" "How the process will be planned?" "What are the expectations from teachers?" must be addressed.

In the second stage, activities should be carried out to establish a bond of trust between teachers and instructors. The main subject of the present study was UbD. UbD training was given to teachers for three days before starting the design process. In this process, it was revealed that the competence of the instructors, their communication with teachers, and their attitude to answer the questions of teachers are very important for teachers. Before proceeding to the main design activities, ice breaker games can be carried out to make all the stakeholders ready for the learning process. A two-way communication between teachers and instructors also facilitates professional learning process.

The tasks expected from teachers should be clearly announced. Information and reminders about the task deadlines will help teachers remain on task.

Detailed feedback should be given to the designs of the teachers. It is also effective, when, the strengths and weakness of the designs are explained in detail and examples specific to the disciplines are provided. To enable documentation, the communication about initial, revised, and final designs should be kept in written format.

Organizing interactive meetings to encourage teachers share and discuss about their work and class implementations. Giving feedback and guidance specific to raised issues in these meetings will contribute to the PD outcomes of teachers.

In later designs, with the consent of the teacher, the instructors can observe the class implementations. After the observation, teachers and the instructors should discuss and make new decisions about their designs.

In long-term studies involving the PD of teachers; when feedback is given to teachers' work, classroom observations and meetings, the instructors should adopt a sincere, communicative, competent, and non-judgmental attitude.

\section{References}

Aelterman, N., Vansteenkiste, M., Van Keer, H., De Meyer, J., Van den Berghe, L., \& Haerens, L. (2013). Development and evaluation of a training on need-supportive teaching in physical education: Qualitative and quantitative findings. Teaching and Teacher Education, 29, 64-75.

Altun, S., \& Yurtseven, N. (2019). Tasarımcı öğretmen: UbD el kitabı. Asos Yayıncilı.

Armour, K. M., \& Yelling, M. (2007). Effective professional development for physical education teachers: The role of informal, collaborative learning. Journal of teaching in physical education, 26(2), 177-200.

Avalos, B. (2011). Teacher professional development in teaching and teacher education over ten years. Teaching and teacher education, 27(1), 10-20.

Ben-Chaim, D., Joffe, N., \& Zoller, U. (1994). Empowerment of elementary school teachers to implement science curriculum reforms. School Science and Mathematics, 94(7), 356-366.

Biggs, J., \& Tang, C. (2011). Train-the-trainers: Implementing outcomes-based teaching and learning in Malaysian higher education. Malaysian Journal of Learning and Instruction, 8, 1-19.

Blank, R. K., \& De Las Alas, N. (2009). The Effects of Teacher Professional Development on Gains in Student Achievement: How Meta Analysis Provides Scientific Evidence Useful to Education Leaders. Washington, DC: Council of Chief State School Officers. Retrieved from https:// files.eric.ed.gov/fulltext/ED544700.pdf.

Branch, R. M. (2009). Instructional design: The ADDIE approach (Vol. 722). Springer.

Bullough, R. V. (2009). Seeking eudaimonia: The emotions in learning to teach and to mentor. In Schutz P., Zembylas M. (eds), Advances in teacher emotion research (pp. 33-53). Springer. 


\section{iejee}

Cavanaugh, B. (2013). Performance feedback and teachers' use of praise and opportunities to respond: A review of the literature. Education and Treatment of Children, 36(1), 111-136.

Chase, S. (2011). Narrative Inquiry: Still a Field in the Making, In N.K. Denzin \& Y.S.Lincoln (Eds.), The SAGE Handbook of Qualitative Research (4th ed.),pp.421-434. Sage

Clarke, D., \& Hollingsworth, H. (2002). Elaborating a model of teacher professional growth. Teaching and teacher education, 18(8), 947-967.

Connelly, F. M., \& Clandinin, D. J. (1990). Stories of experience and narrative inquiry. Educational researcher, 19(5), 2-14.

Crawford, C. (2004). Non-linear instructional design model: eternal, synergistic design and development. British Journal of Educational Technology, 35(4), 413-420.

Dang, T. K. A. (2013). Identity in activity: Examining teacher professional identity formation in the paired-placement of student teachers. Teaching and teacher education, 30, 47-59.

Darling-Hammond, L. (2012). Powerful teacher education: Lessons from exemplary programs. Josey-Bass.

Darling-Hammond, L., Hyler, M. E., \& Gardner, M. (2017). Effective teacher professional development. Learning Policy Institute. Retrieved from https:// files.eric.ed.gov/fulltext/ED606743.pdf.

Desforges, C. (1995). How does experience affect theoretical knowledge for teaching?. Learning and Instruction, 5(4), 385-400.

Desimone, L. M. (2009). Improving impact studies of teachers' professional development: Toward better conceptualizations and measures. Educational Researcher, 38, 181-200.

Ding, M., \& Carlson, M. A. (2013). Elementary teachers' learning to construct high-quality mathematics lesson plans: A use of the IES recommendations. The Elementary School Journal, 113(3), 359-385.

Drost, B. R., \& Levine, A. C. (2015). An analysis of strategies for teaching standards-based lesson plan alignment to preservice teachers. Journal of Education, 195(2), 37-47.

Edmonds, G. S., Branch, R. C., \& Mukherjee, P. (1994). A conceptual framework for comparing instructional design models. Educational technology research and development, 42(4), 55-72.
Fullan, M. (2007). The new meaning of educational change $\left(4^{\text {th }}\right.$ ed.). Teachers College Press.

Garet, M. S., Porter, A. C., Desimone, L., Birman, B. F., \& Yoon, K. S. (2001). What makes professional development effective? Results from a national sample of teachers. American Educational Research Journal, 38, 915-945.

Golombek, P., \& Doran, M. (2014). Unifying cognition, emotion, and activity in language teacher professional development. Teaching and Teacher Education, 39, 102-111.

Guskey, T. R. (2002). Professional development and teacher change. Teachers and teaching, 8(3), 381-391.

Guskey, T. R., \& Yoon, K. S. (2009). What works in professional development?. Phi delta kappan, 90(7), 495-500.

Gustafson, K. L., \& Branch, R. M. (2002). What is instructional design. Trends and issues in instructional design and technology, 16-25.

Global Partnership for Education. (2020). 21st Century Skills: What potential role for the Global Partnership for Education?-A landscape review. https://www.globalpartnership.org/ content/21st-century-skills-what-potential-roleglobal-partnership-education

Haciomeroglu, G. (2018). Emoji nesline öğretmek: öğretmen adaylarının bir matematik etkinliği geliştirmesine yönelik yansıtıcı görüşlerinin incelenmesi [Teaching the Emoji Generations: Examining the Role of Reflections on the Student Teachers' Development of a Mathematical Activity]. International Journal of Educational Studies in Mathematics, 5(1), 11-22.

Hargreaves, A., \& Fullan, M. G. (1992). Understanding teacher development. Teachers College Press.

Harris, T. B., Chung, W., Hutchins, H. M., \& Chiaburu, D. S. (2014). Do trainer style and learner orientation predict training outcomes?. Journal of workplace learning, 26 (5), 331-344.

Kelly, A.V. (1999). The curriculum: Theory and practice (4th ed).Sage.

Li, Y., Chen, X., \& Kulm, G. (2009). Mathematics teachers' practices and thinking in lesson plan development: a case of teaching fraction division. ZDM, 41(6), 717-731.

Lincoln, Y. S., \& Guba, E. G. (1985). Naturalistic Inquiry. Sage 
Mahn, H., \& John-Steiner, V. (2002). The gift of confidence: A Vygotskian view of emotions. In G.Wells \& G.Claxton (Eds.), Learning for life in the 21st century (pp.46-58). Blackwell Publishing.

Maskit, D. (2011). Teachers' attitudes toward pedagogical changes during various stages of professional development. Teaching and teacher education, 27(5), 851-860.

McTighe, J., \& Wiggins, G. (2012). Understanding by design framework. Association for Supervision and Curriculum Development.

Merriam, S. B., \& Tisdell, E. J. (2016). Qualitative research: A guide to design and implementation. John Wiley \& Sons.

Newmann, F. M., King, M. B., \& Youngs, P. (2000). Professional development that addresses school capacity: Lessons from urban elementary schools. American journal of education, 108(4), 259-299.

Nievenn, N. \& van der Hoeven, M. (2011). Building the curricular capacity of teachers: insights from the Netherlands, In P.Patrick \& L.Ria (Eds.), Beginning teachers: a challenge for educational systemsCIDREE Yearbook 2011 (pp.49-64). ENS de Lyon, Institut français de l'éducation.

OECD. (2019). OECD Future of Education and Skills 2030 OECD Learning Compass 2030 A Series Of Concept Notes. https://www.oecd.org/ education/2030-project/teaching-andlearning/learning/learning-compass-2030/

Ozgen, K. (2017). Öğretmen adaylarının matematiği farklı disiplinler ile ilişkilendirme etkinlikleri tasarlama becerileri [The Skills of Prospective Teachers to Design Activities that Connect Mathematics to Different Disciplines]. Inonu University Journal of the Faculty of Education, 20(1), 101-118.

Penuel, W. R., \& Gallagher, L. P. (2009). Preparing teachers to design instruction for deep understanding in middle school earth science. The Journal of the Learning Sciences, 18(4), 461-508.

Pinto, R. (2005). Introducing curriculum innovations in science: Identifying teachers' transformations and the design of related teacher education. Science education, 89(1), 1-12.

Polkinghorne, D. E. (2007). Validity issues in narrative research. Qualitative inquiry, 13(4), 471-486.
Putnam, R. T., \& Borko, H. (2000). What do new views of knowledge and thinking have to say about research on teacher learning? Educational researcher, 29(1), 4-15.

Reiser, R.A., Dempsey, J.V. (2007). Trends and Issues in Instructional Design (2nd ed.). Pearson Education, Inc.

Seeger, V., Wood, S., \& Romans, D. (2018). Questioning for Meaning: Enhancing Questioning Strategies of Teacher Candidates through the Understanding by Design Approach. College Quarterly, 21(3).

Starkey, L., Yates, A., Meyer, L. H., Hall, C., Taylor, M., Stevens, S., \& Toia, R. (2009). Professional development design: Embedding educational reform in New Zealand. Teaching and teacher education, 25(1), 181-189.

Torff, B., \& Sessions, D. (2008). Factors associated with teachers' attitudes about professional development. Teacher Education Quarterly, 35(2), 123-133.

Trilling, B., \& Fadel, C. (2009). 21st Century Skills, Enhanced Edition: Learning for Life in Our Times. Jossey-Bass.

Virgin, R. (2014). Connecting learning: How revisiting big idea questions can help in history classrooms. The Social Studies, 105(4), 1-212.

Voogt, J. M., Pieters, J. M., \& Handelzalts, A. (2016). Teacher collaboration in curriculum design teams: Effects, mechanisms, and conditions. Educational Research and Evaluation, 22(3-4), 121-140.

Vygotsky, L. S. (1994). Extracts from thought and language and mind in society. Language, literacy and learning in educational practice. Clevedon: Multilingual Matters, 45-58.

Yurtseven, N., \& Altun, S., (2018). The Role of SelfReflection and Peer Review in Curriculumfocused Professional Development for Teachers. Hacettepe University Journal of Education, 33 (1), 207-228.

Wayne, A. J., Yoon, K. S., Zhu, P., Cronen, S., \& Garet, M. S. (2008). Experimenting with teacher professional development: Motives and methods. Educational researcher, 37(8), 469-479.

Wiggins, G. P. \& McTighe, J. (2005). Understanding by design (Expanded 2nd ed.). Association for Supervision and Curriculum Development. 
Wiggins, G. P., \& McTighe, J. (2011). The understanding by design guide to creating high-quality units. Association for Supervision and Curriculum Development.

Zaslow, M., Tout, K., Halle, T., Whittaker, J. V., \& Lavelle, B. (2010). Toward the Identification of Features of Effective Professional Development for Early Childhood Educators. Literature Review. Office of Planning, Evaluation and Policy Development, US Department of Education. Retrieved from https://files.eric.ed.gov/fulltext/ED527140.pdf 